\title{
Factors Affecting Housing Products Price in Jakarta Metropolitan Region
}

\author{
Raden Aswin Rahadi ${ }^{1}$, Sudarso Kaderi Wiryono ${ }^{1}$, Deddy Priatmodjo Koesrindartoto ${ }^{1}$, \\ Indra Budiman Syamwil ${ }^{2}$ \\ ${ }^{1}$ School of Business and Management, Institut Teknologi Bandung, Indonesia; \\ ${ }^{2}$ School of Architecture, Planning, and Policy Development, Institut Teknologi Bandung, Indonesia \\ ${ }^{* 1}$ aswin.rahadi@sbm-itb.ac.id
}

\begin{abstract}
This study addresses the issue of factors affecting housing products price in Indonesia, particularly in Jakarta Metropolitan Region. Based on a conceptual model conceived in the study, this preliminary study aims to validate the conceptual model and influencing factors for housing products price. Through a specially designed questionnaire, responses from housing consumers in late 2014 were used to analyse the current housing market products in Jakarta Metropolitan Region. Factors from the conceptual model and information about current housing products in Jakarta Metropolitan Region were combined to produce the questionnaire items. Eleven housing products from various areas and various segmentations in Jakarta Metropolitan Region were applied into the questionnaire. The findings suggested different preference factors for each of the housing development. They also confirm the current housing market conditions in Indonesia are facing overpriced situation. The responses indicate that consumers cannot afford the housing products offered at their current prices. This condition applies for most of the socio-economic and demographics attributes including the housing market segmentation, housing market locations and gender.
\end{abstract}

Keywords: Housing market, consumer preferences, Indonesia, housing price, property, real estate.

\subsection{INTRODUCTION}

Residential product is widely recognized as one of the essential commercial product for people all around the world. So essential for their consumers' life that the purchasing decision for residential products is often committed to a set of complex decision making process and it will require a large sum of monetary funding from the consumers (Daly et al., 2003).

Due to the important position posited by the product, there are increasing numbers of studies about the housing market behavior over the past years. However, the previous studies on market behavior were 
only limited to the extent on theoretical implications for residential markets, and only a few of them studied on the practical implications of a theory of the residential markets. The implications of the residential preference theory are important as it would offer explanation and information about the current condition of the property industry in general and residential market position in detail. The findings from the study are useful for all stakeholders involved in the industry, including the property developers or practitioners, consumers and government.

This study aims to provide answers for residential consumer preference in Jakarta Metropolitan Region, Indonesia. In Indonesia, housing product can be defined as landed house for single family residence, as the concept of flats and shared housing is uncommon. For this study, we focused on the housing consumers since housing product still has the largest market share of the residential market in Indonesia, compared with other residential product, such as apartments or flats. Jakarta Metropolitan Region is chosen for this research as it represents the highest concentration of city population for Indonesia. It also has the largest demographic mix from all around Indonesia, as Jakarta serves as centre of business and government for Indonesia.

The Jakarta Metropolitan area started out as Batavia. When Indonesia was declared independent in August $17^{\text {th }} 1945$, Batavia took the name of Jakarta and was declared as the nation's capital. Over the years, Jakarta has served as the main country's economic, business, and government centre and has been drawing in migrants from all over Indonesia. Due to migration, the overall area of Jakarta has continually expanded, particularly for the residential area, reaching their respective neighbouring provinces of Banten and West Java.

According to the Multidimensional Poverty Index of 2014, 45.9 percent of the populations in Jakarta Metropolitan Region are poor (Wright, 2015). Air quality is similarly poor, putting Jakarta at 112 out of 178 metropolitan jurisdictions (2014). Because of high land prices in central Jakarta as well as of air pollution, most of the populations are increasingly scattered to the surrounding area of Jakarta, notably to the locations such as Bekasi, Serpong, Tangerang, Depok, Bogor, and Cibubur.

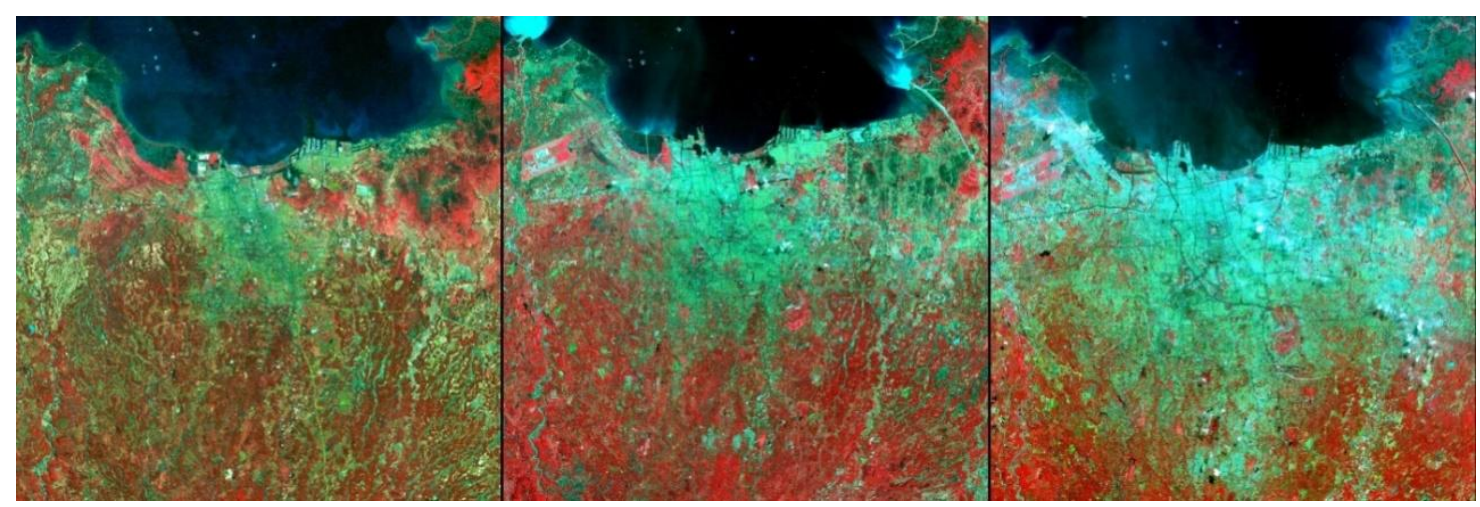

Figure 1: Jakarta Metropolitan Region Growth over time. Left Image Shows the Condition in the Year 
of 1976, while the Right Image Shows the Condition in the Year of 2004. Images courtesy of report from NASA Earth Observatory (2005).

Since 1976, Jakarta Metropolitan Region has developed significantly, as seen by the conglomeration of the green area in Figure 1, which expanded continuously over time. The expansion has widened, from the centre of Jakarta area, to Serpong, Bekasi, Tangerang, Cibubur, and Depok areas. Currently house prices in Jakarta Metropolitan Region have increased significantly. The Global Property Guide (2015) reporting data from the Central Bank of Indonesia, observed that these have inflated by 6.27 percent in the first quarter of 2015.As seen in figure 2(a), the nominal value of the housing price is increasing, however as the inflation rate in Indonesia is climbing, particularly in the year of 2007-2008, during the Asian financial crisis, the real value of the housing product is decreasing, as the sellers must bear the consequence of high inflation rate.
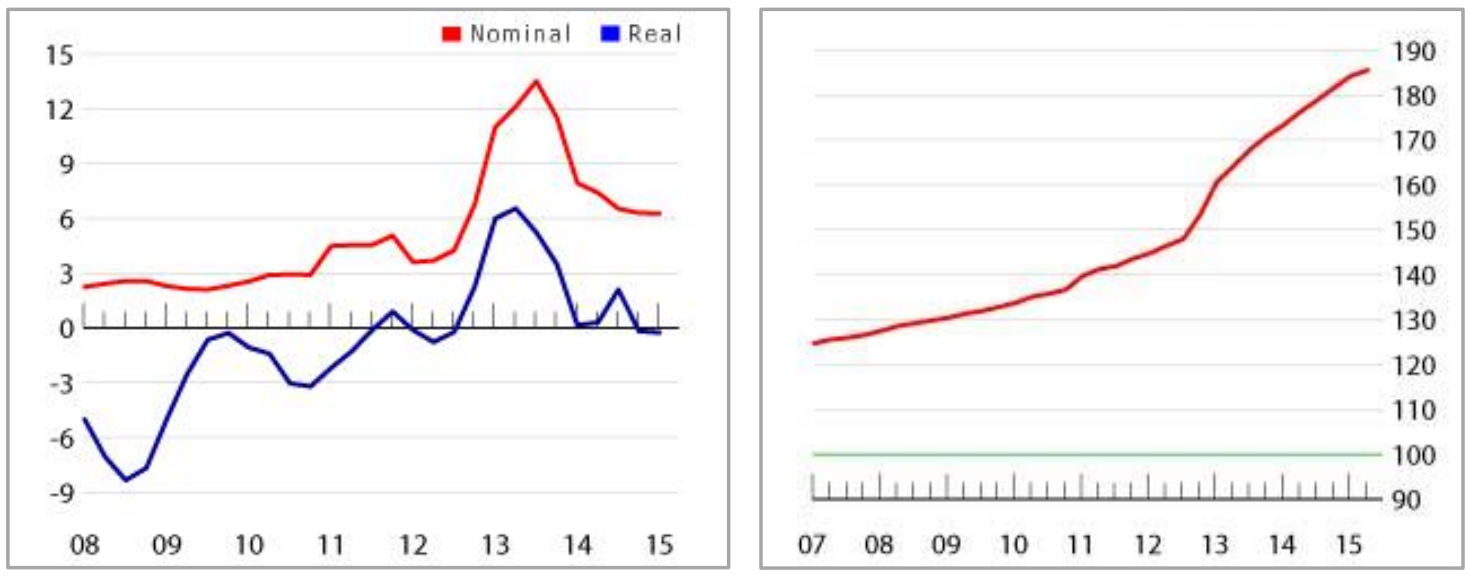

Figure 2(a): Housing Price Change in Jakarta Metropolitan Region (\%).

Figure 2(b): Residential Property Price Index, Composite from 16 Cities Since year 2002 (2002=100). Images courtesy ofreport from Global Property Guide (2015).

This research extends the previous studies by the authors that looked into factors influencing housing product price in Jakarta Metropolitan Region. Previously, the authors conducted several preliminary studies to find the determinant attributes for housing product price in Jakarta Metropolitan Region, starting with the synthesis of literature on influencing factors for housing products (Rahadi et al., 2012) followed by qualitative study on the synthesis results via in-depth interview (Rahadi et al., 2013). In 2014, the authors performed quantitative research based on the previous 2013 study on housing consumers (Rahadi et al., 2014), followed by quantitative researches on housing consumers and real estate developers in 2015 (Rahadi et al., 2015; Rahadi et al., 2015). Based on the research results, the authors have been able to determine the factors influencing housing product price in Jakarta Metropolitan Region. This paper will incorporate the latest findings of the study to address the practical implications of the influencing factors in current housing product development. 
This paper is organized into six sections. The first section consists of the introduction of the research paper. The second section provides an explanation of previous literature studies on residential consumer preferences. The third section discusses the research methodologies. The fourth section explains the data analysis. The fifth section discusses the research findings, and the last section provides the conclusions for this study.

\subsection{LITERATURE REVIEW}

Consumers normally go through a series of steps before committing a purchase. In here, rational choice behaviours underline the process of buying the product. Lerman (1976), Thaler (1980), and Bateman et al. (2002) suggested that consumers always attempt to choose rationally when purchasing a product. This applies to housing consumers, particularly in Indonesia. When selecting a housing product, most consumers begin by identifying the price of the selected objects, their additional positive and negative attributes (location, safety, facility, neighbourhood, and others), weighing the utility.

The first important factor for consumers when making decisions to purchase a residential product is location. As first mentioned by Lord Harold Samuel in 1944, the most important factor for a property product is "location, location, location" (Brodie, 2007). There have been are several studies that address the importance of location in residential purchase decision. Locational proximity to important facilities such as schools, activity center, shopping center, and religious center is considered as important factors to residential consumers when deciding to purchase a residential product. This evidence is supported by Colwell et al. (1985), Sirpal (1994), Gibbons \& Machin (2008), Brandt et al. (2013), and Wen et al. (2014). Besides locational proximity to important facilities, two additional location attributes are important in Indonesian context: proximity to family member's location and work place location. Indonesians, as most South East Asians, greatly uphold family values and prefer to live closely with their closest family members. It is common for a son and daughter to live with or near their parents or brother and sister. Consumers who purchase housing in Serpong area are people who used to live and grow up in the nearby areas of Pondok Indah, Bintaro Jaya, and Puri Indah. This is also in line with several previous researches discussing the distance to workplace and residential price (Adair et al., 2000 and Bina et al., 2006).

In relation to locational proximity to important facilities, the next influential factor for housing product price comes from the ease of access to those important facilities. In Jakarta Metropolitan Region [since public transportation service is unreliable (Sutomo et al., 1993 and Setiawan, 2013)], a majority of the population depends on personal transportation means such as automobiles and motorcycles.

According to Pew Research Center (2015), more than 4 per cent of household owns car, and 85 per cent of household own motorcycles or scooter. In Jakarta, according to the National Statistic Bureau, everyday there are 2.43 million commuters travel in, out, or within the city daily, with 1.38 million of 
them are coming from outside of the city. From the commuters traveling from outside of the city, 70 per cent of them commute using private cars and motorcycles (Budiari, 2015).

Direct toll road access has emerged as one of the major influencing factors for high housing prices (Waddell et al., 1993, Boarnet \& Chaelermpong, 2001 and Vadali, 2008). Large real estate developers such as Bumi Serpong Damai, Alam Sutera, Bintaro Jaya, Grand Wisata, and Gading Serpong are willing to invest in direct toll road access to their area of development to increase the sales of their products. Ease of access also means that there are more than one entrance and exit available to access a real estate development (Smersh \& Smith in 2000 and Molin \& Timmermans in 2003). With heavy traffic, it is important to have secondary or even tertiary alternatives to reach home during busy weekdays.

The next influencing factor for housing product is the physical qualities of the product being offered to consumers. This factor includes façade characteristics (Cetintahra and Cubukcu, 2014), infrastructure condition (Kwanda et al. (2001); Famuyiwa \& Babawale (2014), product specifications (Kwanda et al., (2001) and Epple et al.,(2013), and floor plan design (Xie et al. (2013), Aulia \& Ismail (2013) and Leung et al. (2013).

Attributes of concept do influence housing product price. Evidence includes studies by Blakely \& Snyder (1997), Spetic et al. (2005), Jim \& Chen (2006), Sander \& Polasky (2009), and Singh et al. (2010), discussing the introduction of green concept in housing development. Blakely \& Snyder (1997), La Cour Little \& Malpezzi (2001), Pompe (2008), Le Goix \& Webster (2008), Hapsariniaty et al. (2013) have also discussed the relationship between the introduction of residential cluster concept and its influence towards housing price. Lastly, the introduction of premium facilities into a housing development should influence the housing price being offered. Evidence can be found in the studies by Raymond \& Love (2000) and Feng \& Humpreys (2008).

Other influencing factors for consumer preferences towards housing product price include brand and reputation, with evidence on previous studies by Jiang \& Rosenbloom in 2003, Davison et al. (2009) and Shafiei et al. (2010). The factors of financial condition, with evidence of previous studies by Edelstein \& Lum (2004), Glaeser et al. (2005), and Favara \& Imbs (2010). Last is the factor of livability, with evidence on previous studies performed by Blakely \& Synder (1998), Sander \& Polaskly (2009), Ratchakulpat et al (2009), and Singh et al. (2010).

Having performed the literature synthesis followed by qualitative and quantitative analysis in the research process, the authors were able to create a conceptual model defining the influencing factors for housing product price in Jakarta Metropolitan Region. As seen in figure 3, the influencing factors consist of physical qualities, brand, financial condition, livability, location, accessibility and concept. 


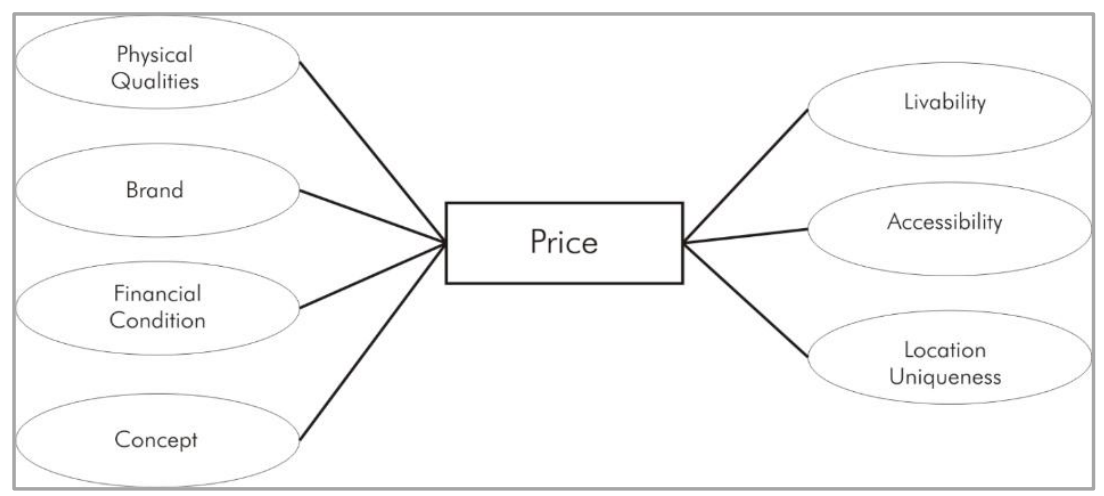

Figure 3: Conceptual Model for Influencing Factors for Housing Products in Jakarta Metropolitan Region (Rahadi et al., 2014)

This research uses the conceptual model to understand the housing consumer behavior towards price in Jakarta Metropolitan region. The conceptual model then will be applied to the current housing market condition in Jakarta Metropolitan Region, to create a questionnaire design that will uncover the current market position of each housing product in the area.

The findings from this study would be useful for mapping the current housing market condition in Jakarta Metropolitan Region. This approach can be justified to bridge the current gaps in the literature for consumer preference in Indonesia. It will also be beneficial practically for all stakeholders involved in the housing industry.

\subsection{METHOD}

A questionnaire survey was conducted in the late 2014. As this study is still considered as preliminary, data was gathered data from a total of 100 respondents comprising current and future house owners identified as housing consumers. The location was in Jakarta Metropolitan Region and its surrounding satellite cities. The age range of the respondents was between 18-56 years old. The data was collected using judgmental sampling with non-sequential approach.

The main aim of the survey was to elicit respondents' preferences when presented with several alternative housing products. It was expected that the consumer's response would enable this study to map the current housing market conditions in Jakarta Metropolitan Region. The respondents were then asked about their willingness to buy the housing product, after learning about the existing attributes embedded in each of the products.

The questionnaire items were grouped into two parts. The first part deals with the demographics information, while the last part deals with the validation of the conceptual model for housing consumers in Jakarta Metropolitan Region. A total of 11 housing products from 10 property developers were 
included in this questionnaire survey. The products are located in all of Jakarta Metropolitan Region area (Alam Sutera, Bogor Nirwana Residence, Bumi Serpong Damai, Citra Gran Cibubur, Depok Permata Regency, Grand Wisata Bekasi, Jababeka Residence, Pantai Indah Kapuk. Summarecon Bekasi, and Spring Hill).

A standard questionnaire format was adopted for each of the eleven housing products as seen in Appendix 1. This was done to prevent bias selection by the respondents. Seven factors (Physical Qualities, Brand, Concept, Location Uniqueness, Ease of Access, Financial Condition, and Livability) and their attributes were included in the questionnaire, in relation to the previous presented pictures. The study adopted the approach by Brown (2003). On each of the items, respondents stated their willingness to purchase the housing at a specific price, judging from their current condition. The price tag for each of the housing product is the current market price during the research process. Respondents answered on the basis of Likert scale of 1-6, with a score of 1 representing high unwillingness to buy and a 6 representing high willingness to buy the a fore mentioned products.

During the process of data collection, confidentiality of the respondent's personal information was maintained. Prior to the research process, the respondents were provided with instructions on completing the questionnaire, the study purpose, and information about data confidentiality. All respondents gave their consent to participate in this study. The research process, from constructing the survey method, data collection, and data analysis was monitored and approved by the university advisers.

\subsection{ANALYSIS AND RESULTS}

This section summarises the findings from the data collected from housing consumers in Jakarta Metropolitan Region. Descriptive statistics were deployed including mean analysis, mode analysis, and analysis of the housing consumers' willingness to buy.

\subsection{Demographic Characteristics of Respondents}

The gender distribution of the respondents' is rather even ( 55 female and 45 male). The bulk of the respondents plan to purchase a house in the southern ( 42 percent) and eastern ( 33 percent) areas of Jakarta Metropolitan Region. Approximately half of the respondents are married (57 percent), and most of the respondents have more than four family members living in their house. More than half of the respondents hold a Bachelor degree (53 percent). 
Table 1: Demography Information of the Respondents

\begin{tabular}{|c|c|c|c|}
\hline \multicolumn{2}{|c|}{ Demographics Information } & \multirow{2}{*}{$\begin{array}{r}\text { Frequency } \\
55\end{array}$} & \multirow{2}{*}{$\begin{array}{r}\text { Percent } \\
55.0 \%\end{array}$} \\
\hline Su & Female & & \\
\hline sex & Male & 45 & $45.0 \%$ \\
\hline \multirow{6}{*}{ Location } & Central & 3 & $3.0 \%$ \\
\hline & East & 33 & $33.0 \%$ \\
\hline & North & 10 & $10.0 \%$ \\
\hline & South & 42 & $42.0 \%$ \\
\hline & West & 9 & $9.0 \%$ \\
\hline & Others & 3 & $3.0 \%$ \\
\hline \multirow{2}{*}{ Marital Status } & Single & 43 & $43.0 \%$ \\
\hline & Married & 57 & $57.0 \%$ \\
\hline \multirow{5}{*}{ Education } & Up to secondary school (high school) & 28 & $28.0 \%$ \\
\hline & Diploma & 12 & $12.0 \%$ \\
\hline & Bachelor's degree & 53 & $53.0 \%$ \\
\hline & Master's degree & 5 & $5.0 \%$ \\
\hline & Doctorate's degree & 2 & $2.0 \%$ \\
\hline \multirow{5}{*}{$\begin{array}{l}\text { Number of family } \\
\text { members in your } \\
\text { house (excluding } \\
\text { you) }\end{array}$} & 1 & 8 & $8.0 \%$ \\
\hline & 2 & 12 & $12.0 \%$ \\
\hline & 3 & 25 & $25.0 \%$ \\
\hline & 4 & 26 & $26.0 \%$ \\
\hline & $>4$ & 29 & $29.0 \%$ \\
\hline
\end{tabular}

*Respondents were allowed to choose more than one location respondents' purchasing characteristics. Most of the respondents (60 percent) already own a house prior to the decision to purchase next house (60 percent). After purchasing a new house, they plan to occupy the new house (71 percent). Most of them (60 percent) were prepared to pay up to 100 million rupiah for the house down payment and they also prepare to spare up to 3 million rupiah per months for the house installment payment (60 percent). Most of the respondents have a combined monthly family income of five to ten million rupiah, and they prefer to purchase their house using housing mortgage or KreditPemilikanRumah (KPR). 
Table 2: Purchasing Characteristics of Respondents

\begin{tabular}{|c|c|c|c|}
\hline \multicolumn{2}{|c|}{ Demographics Information } & Frequency & \multirow{2}{*}{$\begin{array}{r}\text { Percent } \\
60.0 \%\end{array}$} \\
\hline \multirow{2}{*}{ Do you own a house before? } & Yes & 60 & \\
\hline & No & 40 & $40.0 \%$ \\
\hline \multirow{3}{*}{ What is your plan for the purchased house? } & Owner occupied & 71 & $71.0 \%$ \\
\hline & Rent & 25 & $25.0 \%$ \\
\hline & Sell & 4 & $4.0 \%$ \\
\hline \multirow{5}{*}{$\begin{array}{l}\text { Fund for down payment? In million Indonesian } \\
\text { Rupiah (IDR) }\end{array}$} & $<100$ & 60 & $60.0 \%$ \\
\hline & $100-300$ & 25 & $25.0 \%$ \\
\hline & $300-500$ & 5 & $5.0 \%$ \\
\hline & $500-1000$ & 8 & $8.0 \%$ \\
\hline & $>1000$ & 2 & $2.0 \%$ \\
\hline \multirow{5}{*}{$\begin{array}{l}\text { Fund for installment per month? In million } \\
\text { Indonesian Rupiah (IDR) }\end{array}$} & $<3$ & 60 & $60.0 \%$ \\
\hline & $3-5$ & 25 & $25.0 \%$ \\
\hline & $5-10$ & 5 & $5.0 \%$ \\
\hline & $10-15$ & 8 & $8.0 \%$ \\
\hline & $>15$ & 2 & $2.0 \%$ \\
\hline \multirow{6}{*}{$\begin{array}{c}\text { Monthly family income? In million Indonesian } \\
\text { Rupiah (IDR) }\end{array}$} & $<3$ & 5 & $5.0 \%$ \\
\hline & $3-5$ & 13 & $13.0 \%$ \\
\hline & $5-10$ & 32 & $32.0 \%$ \\
\hline & $10-15$ & 15 & $15.0 \%$ \\
\hline & $15-20$ & 16 & $16.0 \%$ \\
\hline & $>20$ & 19 & $19.0 \%$ \\
\hline \multirow{4}{*}{ Proposed ownership scheme } & Hard cash (3 months installment) & 5 & $5.0 \%$ \\
\hline & Hard cash (12 months installment) & 4 & $4.0 \%$ \\
\hline & Cash installment (up to five years) & 26 & $26.0 \%$ \\
\hline & Housing mortgage (KPR) & 65 & $65.0 \%$ \\
\hline
\end{tabular}

\subsection{Mean Analysis}

Prior to calculating the mean analysis, the data collected was tested for reliability. Using SPSS, the data collected was found to have a Cronbach $\alpha$ score of 0.986 , indicating that it was reliable.

Table 3: Mean analysis results by factor category across all housing products.

\begin{tabular}{|c|c|c|c|c|c|c|c|}
\hline ltem & $\begin{array}{l}\text { Physical } \\
\text { Qualities }\end{array}$ & Brand & Concept & Accessibility & Location & $\begin{array}{l}\text { Financial } \\
\text { Condition } \\
\end{array}$ & Livability \\
\hline 1 Depok Permata Regency & 3.040 & 3.150 & 3.420 & 3.290 & 3.080 & 3.250 & 3.100 \\
\hline 2 Bogor Nirwana Residence & 3.240 & 3.290 & 3.440 & 3.460 & 3.240 & 3.310 & 3.230 \\
\hline 3 Pantai Indah Kapuk & 3.240 & 3.270 & 3.150 & 3.100 & 2.970 & 2.780 & 3.040 \\
\hline 4 Spring Hill & 3.080 & 3.180 & 3.230 & 3.250 & 3.100 & 3.010 & 3.050 \\
\hline 5 Bumi Serpong Damai & 3.450 & 3.320 & 3.420 & 3.280 & 3.150 & 3.170 & 3.360 \\
\hline 6 Alam Sutera & 3.730 & 3.580 & 3.610 & 3.450 & 3.340 & 3.080 & 3.510 \\
\hline 7 Grand Wisata Bekasi & 3.560 & 3.410 & 3.510 & 3.310 & 3.310 & 3.210 & 3.180 \\
\hline 8 Citra Gran Cibubur & 3.630 & 3.440 & 3.500 & 3.240 & 3.200 & 3.190 & 3.320 \\
\hline 9 Summarecon Bekasi & 3.590 & 3.560 & 3.410 & 3.320 & 3.270 & 3.160 & 3.300 \\
\hline 10 Jababeka Residence: Oscar Residence & 3.370 & 3.370 & 3.270 & 3.030 & 3.110 & 2.900 & 3.180 \\
\hline 11 Jababeka Residence: Simprug Garden & 3.040 & 3.060 & 3.060 & 2.970 & 2.920 & 3.000 & 2.990 \\
\hline
\end{tabular}

Table 3 shows the different results for each of the housing products. The respondents have presented the strengths and weaknesses for each development. For Depok Permata Regency housing development, physical qualities scored the lowest mean (3.040), while concept scored the highest mean (3.420). The development of Bogor Nirwana Residence scored their lowest mean value (3.230) for livability category and their highest mean value of (3.460) for accessibility category. Pantai Indah Kapuk 
development scored their highest mean value of (3.270) for category of brand with lowest mean (2.780) for financial condition category. For Spring Hill development, the lowest mean value is conceived as their financial condition category (3.010) and their highest mean value is achieved for their accessibility value (3.250). Bumi Serpong Damai development scored their lowest mean value of 3.150 for location category and 3.450 for their physical quality category. The Alam Sutera development has the lowest mean value for financial condition category (3.080) and the highest mean value for physical quality category (3.730). The housing development of Grand Wisata Bekasi has the lowest mean value of (3.180) for their livability category and the highest mean value of 3.560 for their physical quality category. Citra Gran Cibubur has the lowest mean value for their financial condition category (3.190) and the highest mean value for physical quality category (3.630). For Summarecon Bekasi housing development, it has the lowest mean value for financial condition category (3.160) and the highest mean value for physical quality category (3.590). For Oscar Residence in Jababeka Residence, the lowest mean value is scored by financial condition category (2.900) and the highest mean value is scored by the physical quality and brand categories (3.370). Finally, for Simprug Residence in Jababeka Residence, the lowest mean value is scored by location category (2.920) and the highest mean value is scored by brand and concept categories (3.060).

Overall, the highest mean value for all of the housing development is scored by the physical quality category for Alam Sutera housing development (3.730). The lowest mean value for all of the housing development is scored by the financial condition category for Pantai Indah Kapuk housing development (2.780). From all eleven housing developments pitched in this research, six of them have the highest mean value scored in physical quality category, while six have the lowest mean value scored in financial condition category.

\subsection{Mode Analysis}

A mode analysis was also undertaken for a further insight. Results are as in Table 4.

Table 4: Mode analysis results by factor categories across all housing products.

\begin{tabular}{|c|c|c|c|c|c|c|c|c|}
\hline No. & Item & Physical Qualities & Brand & Concept & Accessibility & Location & $\begin{array}{l}\text { Financial } \\
\text { Condition }\end{array}$ & Livability \\
\hline 1 & Depok Permata Regency & 3 & 3 & 4 & 3 & 3 & 3 & 3 \\
\hline 2 & Bogor Nirwana Residence & 3 & 3 & 3 & 4 & 3 & 3 & 3 \\
\hline 3 & Pantai Indah Kapuk & 3 & 3 & 3 & 4 & 3 & 1 & 4 \\
\hline 4 & Spring Hill & 4 & 4 & 4 & 4 & 4 & 3 & 4 \\
\hline 5 & Bumi Serpong Damai & 4 & 4 & 4 & 4 & 4 & 4 & 4 \\
\hline 6 & Alam Sutera & 4 & 4 & 4 & 4 & 4 & 4 & 4 \\
\hline 7 & Grand Wisata Bekasi & 4 & 3 & 3 & 3 & 3 & 3 & 3 \\
\hline 8 & Citra Gran Cibubur & 4 & 4 & 4 & 3 & 3 & 3 & 4 \\
\hline 9 & Summarecon Bekasi & 4 & 4 & 4 & 4 & 4 & 3 & 4 \\
\hline 10 & Jababeka Residence: Oscar Residence & 4 & 4 & 4 & 3 & 3 & 3 & 3 \\
\hline 11 & Jababeka Residence: Simprug Gorden & 3 & 3 & 3 & 3 & 3 & 3 & 3 \\
\hline
\end{tabular}

The results suggest that the mode analysis does provide additional information about the reasoning behind the respondents' choice. As seen from the mode analysis, Bumi Serpong Damai, Alam Sutera, and Summarecon Bekasi all have the most positive answers on willingness to purchase by the 
respondents, while Pantai Indah Kapuk has a score of 1 (unwilling to purchase) for the financial condition category. This is quite to be expected, as current housing development growth in Jakarta Metropolitan Region is more focused on Serpong and Bekasi area, where all of those housing developments take place.

\subsection{Willingness to Purchase}

For the final question, respondents were asked whether they willing to purchase the housing product under the current condition offered by each of the property developers, and with the current price offered by each of the property developers.

Table 5: Consumers' willingness to purchase for each of the housing products.

\begin{tabular}{|c|c|c|c|c|c|}
\hline \multirow[t]{2}{*}{ No. } & \multirow[t]{2}{*}{ Item } & \multirow[t]{2}{*}{ Price (in IDR) } & \multirow[t]{2}{*}{ Price (in US\$) } & \multicolumn{2}{|c|}{$\begin{array}{c}\text { Are You Willing To Buy } \\
\text { This House? }\end{array}$} \\
\hline & & & & No & Yes \\
\hline 1 & Depok Permata Regency & $475,000,000$ & 35,714 & 70 & 30 \\
\hline 2 & Bogor Nirwana Residence & $580,000,000$ & 43,609 & 69 & 31 \\
\hline 3 & Pantai Indah Kapuk & $3,750,000,000$ & 281,955 & 91 & 9 \\
\hline 4 & Spring Hill & $1,400,000,000$ & 105,263 & 82 & 18 \\
\hline 5 & Bumi Serpong Damai & $1,600,000,000$ & 120,301 & 76 & 24 \\
\hline 6 & Alam Sutera & $4,800,000,000$ & 360,902 & 85 & 15 \\
\hline 7 & Grand Wisata Bekasi & $1,700,000,000$ & 127,820 & 78 & 22 \\
\hline 8 & Citra Gran Cibubur & $2,000,000,000$ & 150,376 & 80 & 20 \\
\hline 9 & Summarecon Bekasi & $1,550,000,000$ & 116,541 & 76 & 24 \\
\hline 10 & Jababeka Residence: Oscar Residence & $1,577,000,000$ & 118.571 & 84 & 16 \\
\hline 11 & Jababeka Residence: Simprug Garden & $700,000,000$ & 52,632 & 75 & 25 \\
\hline & Note: 1 USS in July 2016 is equal to IDR 13300 & & & & \\
\hline
\end{tabular}

Table 5 presents the final results of whether the respondents are willing to purchase those houses, judging from the price and current conditions. As seen in the results, most of the respondents were unwilling to purchase the products, even when the price offered are proposed in various value segmentation, ranging from 475 million rupiah (US\$ 35.714), up to 4.8 billion rupiah (US\$ 360.902).

\subsection{DISCUSSION}

This section will try to delve into the practical and theoretical implications for consumers' preference for housing product in Jakarta Metropolitan Region. It will also present the limitations and further research opportunities from this study finding.

\subsection{Practical Implications}

The findings on mean analysis indicate that contrary to the reasons for current common practice performed by the property practitioners when determining housing price, housing consumers do have their own system of preferences and analysis for each of property developers' housing products strengths and weaknesses. With the current model presented in this research, property developers can follow up on identifying each of their own products selling points, and capitalise their potentials while 
improving their deficiencies.

The mean analysis results suggest that all of the responses do not have any indication of absolutely positive response on their willingness to buy. Most of the responses are ranged between score of 2 (unwilling to buy) up to 4 (slightly willing to buy). This is worrying as it means that most of the housing products being offered in the Jakarta market are not attractive enough to their consumers. The category of physical quality has the highest mean value responses, while the category of financial condition has the lowest mean value responses.

These findings are also supported by the results of the consumers' willingness to purchase analysis. The results show that less than 30 percent of the respondents are willing to purchase all of the eleven property products being offered in the questionnaire at their respective prices. This suggests that the current housing price offered by the property developers, for all of the location, with all of price segmentations, and all of the conditions offered by the development are overpriced from consumers' point of view. The result is consistent with the reports from several property consultants such as RLB (2015), Colliers International (2014), and Global Property Guide (2015) that portrayed a housing market slowdown in Indonesia. This finding is also somewhat consonant with the current situation in the country where 20.5 percent of the country's total populations do not own a house (BeritaSatu, 2014) and 40 percent of the country's total populations cannot afford to purchase a house (Ramadhiani, 2014).

Finally, from the mode analysis, we can see which housing products are more accepted by housing consumers. This finding is important and can be followed up to produce a transparent report on each housing developer's performance and condition. It would be beneficial for housing consumers and also for government.

\subsection{Theoretical Implications}

In terms of theoretical implications, we can confirm that there is a possibility to develop a conceptual model for housing consumers' preference. The findings for housing consumers' preferences in each of the housing development location can be useful to develop a characteristic model for housing consumers in Jakarta Metropolitan Region. This study has shown that there are distinctive differentiations between each of the housing products being offered, even if offered at nearby location by the same property developers. As the study on the property in Indonesia is still considered to be scarce, the findings in this study should be valuable for the body of knowledge and property theory development in Indonesia.

\subsection{Limitations and Further Research}

In this research, we have identified four limitations and their possible consequences. The first one is the locational limitations. As the sample of respondents gathered for this research come from the area of 
Jakarta Metropolitan Region, the results of this study might not applicable in other regions or countries. The second limitation is the timeline of this study. As this research is performed in the late of year 2014, different results might apply in the future as this survey only captures a certain window of time.

The third limitation of this study is the limited number of respondents. Using the confidence interval and confidence level diagram provided by Israel (1992), the accountability of this population calculation is represented with represents confidence level of $95 \%$ and confidence interval of $10 \%$. A higher confidence interval can be achieved with a greater number of respondents. The final limitation of this study is the random locational preference from the respondents. Although all of the respondents have been provided with complete information about each of the housing products, there are possibilities that a considerable amount of the housing products are not recognised by the respondents.

There are opportunities for this study to be expended based on the limitations of this study. The conceptual model and questionnaire construct can be reapplied in different regions or countries. The research model can also be replicated with a greater number of respondents and careful respondents' demographics profile segmentation. Finally, the conceptual model and questionnaire construct can be re-administered into different types of residential products, such as apartments or flats.

\subsection{CONCLUSIONS AND RECOMMENDATIONS}

This study produces one of the initial studies on consumer preferences towards housing product price. It identifies the factors influencing housing product price. Given that, this study is the first to be conducted in Jakarta Metropolitan region and Indonesia, the research findings have strong significance for the property market in the area, as well as contributing to the property development theories.

The main practical implication of this study is the strengths and weaknesses map of housing developments in all areas in Jakarta Metropolitan region. This map should be useful for both consumers and property developer, as well as for government. It would benefit the consumers as it provides them with transparent information about the current condition of a housing development. It would be beneficial for the property developers as it shows them the potentials and deficiencies of the current product they marketed. Actions could be made to improve the sales of their products. In the future, it would also be favourable for them as it provides them with historic information about their own products strengths and weaknesses. Lastly, it would be constructive for the government to create better rules and regulations for property industries sustainability in Indonesia.

This study's main contribution for body of knowledge is the conceptual model and characteristics map of housing preference for each of housing products in each location. It would provide a varied procedure for property practitioners to conduct their own SWOT (Strength, Weakness, Opportunity, and Threat) analysis, compared with their current regular approach. 
Based on the study results, we propose several recommendations that are useful for the current housing industry in Jakarta Metropolitan Region:

- Housing developers should start developing their products based on their respective consumer's preferences. The research outcome shows that most of the current housing products offered in the market are not attractive enough for the consumers to purchase. By communicating with the consumers, housing developers would be able to create products that are both good and useful.

- The current market price for housing products is overpriced. This phenomenon serves as the first indication of market bubble in the area (Smith and Smith, 2006). With this in mind, government and real estate organizations should start to treat it cautiously, to prevent the events of real estate market bubble.

- In relation to the overpriced housing situation, and the fact that most of the total populations in Indonesia cannot afford to purchase house, creative approaches should be taken by the government to address the issue. With number of populations growing exponentially each year, the supply of affordable housing has become a pressing concern of the nation.

\subsection{REFERENCES}

Adair, A., McGreal, S., Smyth, A., Cooper, J. and Ryley, T. (2000). House prices and accessibility: The testing of relationships within the Belfast urban area. Housing Studies, Vol. 15, No. 5, pp. 699-716.

Aulia, D. N. and Ismail, A. M. (2013). Residential Satisfaction of Middle Income Population: Medan city. Procedia-Social and Behavioral Sciences, 2013, Vol. 105, pp. 674-683.

Bateman, I. J., Carson, R. T., Day, B., Hanemann, M., Hanley, N., Hett, T., Jones-Lee, M., Loomes, G., Mourato, Susana, Ozdemiroglu, Ece, Pearce, David, Sugden, R. and Swanson, J. (2002).Economic valuation with stated preference techniques: a manual.Edward Elgar, Cheltenham, UK.

BeritaSatu. (2014). 20,5\% Penduduk Indonesia TidakMemilikiRumah (20,5\% of Indonesian Population Do Not Own a House).BeritaSatu. Available at: http://www.beritasatu.com/hunian/208034-205penduduk-indonesia-tidak-memiliki-rumah.html (Accessed 10 August 2015).

Bina, M., Kockelman, K. and Suescun, D. (2006). Location Choice vis-á-vis Transportation: the Case of Recent Home Buyers. Proceedings of the 85th Annual Meeting of the Transportation Research Board, 2006.

Blakely, E. J., \& Snyder, M. G. (1998).Fortress America: Gated Communities in the United States. Washington, D.C.: Brookings Institution Press.

Boarnet, M. G. and Chalermpong, S. (2001). New Highways, House Prices, and Urban Development: A Case Study of Toll Roads in Orange County, CA. Housing Policy Debate, Vol. 12, No. 3, pp. 575605.

Brandt, S., Maennig, W. and Richter, F. (2013). Do Places of Worship affect Housing Prices? Evidence 
from Germany.Hamburg Contemporary Economic Discussions, 2013, No. 48.

Brodie, S. (2007).It's location, location, location for Land Secs. Telegraph. Available at: http://www.telegraph.co.uk/finance/2819464/ItslocationlocationlocationforLandSecs.html (Accessed 18 January 2015).

Brown, T. C. (2003). "Introduction to Stated Preference Methods", in Champ, P. A., Boyle, K. J., and Brown, T. C. (Ed).A Primer on Nonmarket Valuation. Springer Netherlands, The Netherlands, pp. 99-110.

Cetintahra, G.E. and Cubukcu, E. (2014). The Influence of Environmental Aesthetics on Economic Value of Housing: An Empirical Research on Virtual Environments. Journal of Housing and the Built Environment, DOI 10.1007/s10901-014-9413-6.

Colliers International. (2014). Research and Forecast Report: Jakarta Property Market Report. Colliers International.4 ${ }^{\text {th }} \quad$ Quarter 2014. Available at: http://www.colliers.com//media/files/marketresearch/apac/indonesia/researchandforecast-jakarta-4q2014.pdf?la=en-gb (Accessed 13 October 2015).

Colwell, P. F., Gujral, S. S. and Coley, C. (1985).The Impact of a Shopping Center on the Value of Surrounding Properties.Real Estate Issues, Vol. 10 No. 1, pp. 35-39.

Daly, J., Gronow, S., Jenkins, D., \&Plimmer, F. (2003). Customer behavior in the valuation of residential property: A comparative study in the UK, Ireland and Australia. Journal of Property Management, 295-314.

Davison, N., Goodier, C., Gibb, A., Austin, S., Saker, J., \& Gregory, C. (2009).Factors Influencing the Market for Branded Mass Costumized Buildings. Loughborough University, 1-10.

Earth Observatory.(2005). Urban Growth in Jakarta, Indonesia.NASA. Available at: http://earthobservatory.nasa.gov/IOTD/view.php?id=5693 (Accessed 13 October 2015).

Edelstein, R.H. and Lum, S.K. (2004) House Prices, Wealth Effects, and the Singapore Macroeconomy.Journal of Housing Economics, Vol. 13, No. 4, pp. 342-367.

Environmental Performance Index. (2014). Issue Ranking: Air Quality in Indonesia. Environmental Performance Index. Available at: http://epi.yale.edu/epi/issue-ranking/air-quality (Accessed 13 October 2015).

Epple, D., Quintero, L., and Sieg, H. (2013).Estimating Hedonic Price Functions when Housing Quality is Latent.Manuscript, May 2013.

Famuyiwa, F. and Babawale, G.K. (2014). Hedonic Values of Physical Infrastructure in House Rentals, Journal of Facilities Management, Vol. 12 Iss: 3

Favara, G. and Imbs, J.M. (2010).Credit Supply and the Price of Housing.CEPR Discussion Paper No. 
DP8129, pp. 1-45.

Feng, X. and Humphreys, B. R. (2008).Assessing the Economic Impact of Sports Facilities on Residential Property Values: A Spatial Hedonic Approach.Working Paper Series, 2008, International Association of Sports Economists, No. 08-12.

Gibbons, S. and Machin, S. (2008). Valuing School Quality, Better Transport, and Lower Crime: Evidence from House Prices. Oxford Review of Economic Policy, Vol. 24, No. 1, pp. 99-119.

Glaeser, E.L., Gyourko, J. and Saks, R. (2005). Why Have Housing Prices Gone Up? National Bureau of Economic Research, No. W11129.

Global Property Guide. (2015). Indonesia's property market pauses. Global Property Guide. Available at: http://www.globalpropertyguide.com/Asia/indonesia/Price-History (Accessed 13 October 2015).

Hapsariniaty A.W. (2013). Analisis Perbandingan Preferensi Masyarakat Golongan Menengah Dalam Memilih Hunian pada Gated Communities di Kawasan Kota dan Pinggiran Kota Bandung: StudiKasusKec. Kiara CondongdanKec.Parongpong (Comparative Analysis of Middle-Class' Preferences Choosing to Live in Gated Communities in the Urban and Suburban area of Bandung: Case Study Kec. Kiara Condong and Kec.Parongpong).Master Thesis, School of Architecture, Planning, and Policy Development, InstitutTeknologi Bandung, Bandung, September 2013.

Hough, D. E., \&Kratz, C. G. (1983). Can 'good' architecture meet the market test? Journal of Urban Economics , pp. 56-67.

Jiang, P. Rosenbloom, B. (2005). Customer Intention to Return Online: Price Perception, AttributeLevel Performance, and Satisfaction Unfolding Over Time. European Journal of Marketing. Vol. 39, No. 1. Pp. 150-174.

Jim, C.Y. and Chen, W.Y. (2006).Impacts of Urban Environmental Elements on Residential Housing Prices in Guangzhou (China).Landscape and Urban Planning. Vol. 78 No. 4, pp. $422-434$.

Kwanda, T., Rahardjo, J. andWardani, M.K. (2001).Analisa Kepuasan Penghuni Perumahan Sederhana di Denpasar Berdasarkan Fakto Lokasi, Prasarana, Sarana, Kualitas Bangunan, Desain, dan Harga (Affordable Housing Tenant Satisfaction Analysis in Denpasar Based on Location, Infrastructure, Facilities, Building Quality, Design and Price Factors). DimensiTeknikArsitektur. Vol. 29, No. 2, 2001, pp. 117-125.

LaCour-Little, M. and Malpezzi, S. (2001).Gated Communities and Property Values.Manuscript.

Le Goix, R., \& Webster, C. J. (2008).Gated Communities.Geography Compass, Vol. 2, No. 4, pp. 11891214.

Leung, C. K. Y., Ma, W. Y. and Zhang, J. (2013). The Market Valuation of Interior Design and Developers strategies: a simple Theory and some Evidence. Munich Personal RePec Archive 
(MPRA).

Lerman, S. R. (1976). Location, housing, automobile ownership, and mode to work: a joint choice model. Transportation Research Record, 610, pp. 6-11.

Molin, E.J.E. and Timmermans, H.J.P. (2003). Accessibility Considerations in Residential Choice Decisions: Accumulated Evidence from the Benelux. Annual Transportation Research Board Meeting, Jan 2003, Washington D.C., Meeting Publication, pp. 1-12.

Picard, N., Antoniou C., \& de Palma A. (2010).Econometric Models, SustainCity Working Paper, 2.4, THEMA, Université de Cergy-Pontoise.

Pompe, J. (2008). The Effect of a Gated Community on Property and Beach Amenity Valuation.Land Economics, Vol. 84, No. 3, pp. 423-433.

Rahadi, R.A., Wiryono, S.K., Koesrindartoto, D.P. and Syamwil, I.B. (2012). Relationship between Consumer Preferences and Value Propositions: A Study of Residential Product. 2012 ASEAN Conference on Environment-Behavior Studies; July 16-18, 2012, Bangkok; Procedia-Social and Behavioral Sciences, pp. 1-10.

Rahadi, R.A., Wiryono, S.K., Koesrindartoto, D.P. and Syamwil, I.B. (2013).Factors Influencing Housing Product Value and Price in Jakarta Metropolitan Region.2013 AMER International Conference on Quality of Life; Nov 8, 2013, Langkawi: Procedia - Social and Behavioral Sciences. pp. 368- 378.

Rahadi, R.A., Wiryono, S.K., Koesrindartoto, D.P., and Syamwil, I.B. (2014).Improved Consumer Preferences Attributes Analysis for Housing Product Price in Indonesia.International Journal of Applied Business and Economic Research.Vol. 12, No. 4, pp. 1367-1389.

Rahadi, R.A., Wiryono, S.K., Koesrindartoto, D.P., and Syamwil, I.B. (2015).Factors influencing the price of housing in Indonesia.International Journal of Housing Markets and Analysis. Vol. 8, Iss. 2, pp. 169-188.

Rahadi, R.A., Wiryono, S.K., Koesrindartoto, D.P., and Syamwil, I.B. (2015).Comparison of the property practitioners and consumer preferences on housing prices in the Jakarta metropolitan region.International Journal of Housing Markets and Analysis.Vol. 8, Iss. 3, pp. 335-358.

Ramadhani, A. (2014). 40 Persen Penduduk Indonesia Tidak Mampu Beli Rumah (40 Percent of Indonesian Populations Cannot Afford to Buy a House).Kompas. Available at: http://properti.kompas.com/read/2014/12/10/172518521/40.Persen.Penduduk.Indonesia.Tidak.Ma mpu.Beli.Rumah (Accessed 10 August 2015).

Raymond, Y. C. and Love, P. E. (2000).Measuring residential property values in Hong Kong.Property Management, Vol. 18, No. 5, pp. 366-374.

Rosen, S. (1974).Hedonic Prices and Implicit Markets: Product Differentiation in Pure Competition. 
The Journal of Political Economy , pp. 34-55.

RLB. (2015). Indonesia Report: Construction Market Update. RLB.Iss. 2, December 2014. Available at: http://rlb.com/wp-content/uploads/2015/01/indonesia-report-december-14.pdf $\quad$ (Accessed 13 October 2015).

Sander H. A. and Polasky S. (2009). The Value of Views and Open Space: Estimates From a Hedonic Pricing Model for Ramsey County, Minnesota, USA. Land Use Policy, Vol. 26, No. 3, pp. 837 845 .

Setiawan, R. (2013). Fixing Indonesia's Public Transport Woes. The Jakarta Globe. Available at: http://thejakartaglobe.beritasatu.com/opinion/commentary/fixingindonesiaspublictransportwoes/ (Accessed 18 January 2015).

Shafiei, M. W., Foo, F. S., Said, I., \&Omran, A. (2010). Malacca House Buyers' Housing Preferences in Malaysian New Residential Market.ANNALS of Faculty Engineering Hunedoara - International Journal of Engineering , pp. 217-226.

Singh, V. S., Pandey, D. N. and Chaudhry, P. (2010). Urban Forests and Open Green Spaces: Lessons for Jaipur, Rajasthan, India. RSPCB Occasional Paper, Vol. 1, pp. 1-23.

Sirpal, R. (1994). Empirical Modeling of the Relative Impacts of Various Sizes of Shopping Centers on the Values of Surrounding Residential Properties. Journal of Real Estate Research, Vol. 9, No. 4, pp. 487-505.

Smersh, G. T. and Smith, M. T. (2000). Accessibility Changes and Urban House Price Appreciation: a Constrained Optimization Approach to Determining Distance Effects. Journal of Housing Economics, Vol. 9, No. 3, pp. 187-196.

Smith, M. H. and Smith, G. (2006).Bubble, Bubble, Where's the Housing Bubble?Brookings Papers on Economic Activity, Vol. 1, pp. 1-67.

Spetic, W., Kozak, R., and Cohen, D. (2005).Willingness to Pay and Preferences for Healthy Home Factors in Canada.Forest Products Journal, Vol. 55 No. 10, pp. 19-24.

Sutomo, H., Dikun, S., Tumewu, W. (1993). Transport Problems, Policies and Current Research and Education in Indonesia. IATSS Research, Vol. 17 No. 1, pp. 43-51.

Thaler, R. (1980).Toward a positive theory of consumer choice. Journal of Economic Behavior \& Organization, Vol.1, No. 1, pp. 39-60.

Wen H., Zhang Y. and Zhang, L. (2014). Do Educational Facilities Affect Housing Price? An empirical study in Hangzhou, China.Habitat International, Vol. 42, pp. 155-163.

Waddell, P., Berry, B. J. and Hoch, I. (1993). Residential Property Values in a Multinodal Urban Area: New Evidence on the Implicit Price of Location. The Journal of Real estate Finance and 
Economics, Vol. 7, No. 2, pp. 117-141.

Wright, E. (2015). Poverty in Jakarta.The Borgen Project. Available at: http://borgenproject.org/poverty-jakarta/ (Accessed 13 October 2015).

Wough, F. (1928).Quality factors influencing vegetable prices. Journal of Farm Economics , pp. 1-18.

Vadali, S. (2008). Toll Roads and Economic Development: Exploring Effects on Property Values. The Annals of Regional Science, Vol. 42, No. 3, pp. 591-620.

Vandell, K. D., \& Lane, J. S. (1989).The economics of architecture and urban design: some preliminary findings. Real Estate Economics, Vol. 17, No. 2, pp. 235-260.

Xie, X. B., Bu, X. Q., Zheng, M. J. and Wen, H. Z. (2013).An Empirical Study on Influencing Factors of Residential Location Choice in Hangzhou, China.Applied Mechanics and Materials, Vol. 357, pp. 1747-1751. 


\section{APPENDIX 1}

\section{Example of Survey Questions for this Research}

\section{Questions for Depok Permata Regency Housing Development}

The picture below contains information about the aforementioned housing product information. Please provide the most honest answers based on the given information. For further information about Depok, Permata Regency housing development can be seen on their official website at http://permatadepokgroup.com/permata_depok_regency.html.

Please answer the questionnaire item with Likert scale of 1 to 6 , your unwillingness or willingness to purchase the housing development based on given information.

\section{Perumahan di kawasan DEPOK Jakarta Selatan}
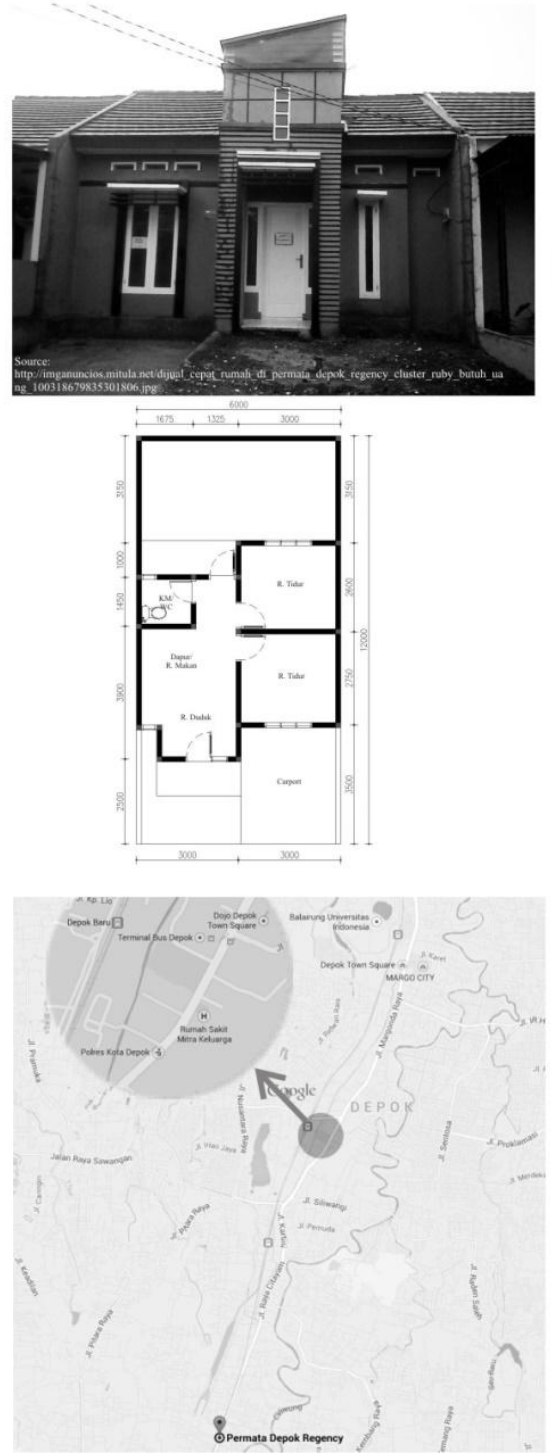

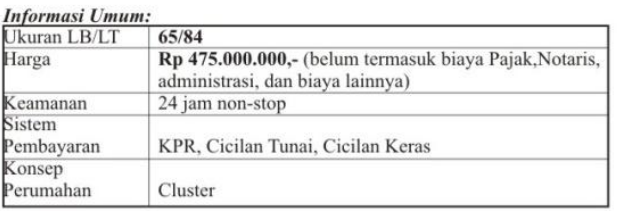

Spesifikasi Produk:

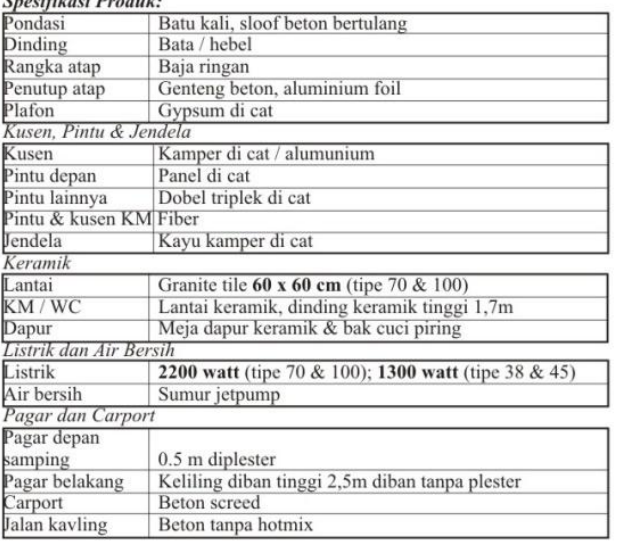

Fasilitas:

\begin{tabular}{|c|c|}
\hline arak ke jalan tol terdekat & $10 \mathrm{~km}$ (Tol Jagorawi) \\
\hline $\begin{array}{l}\text { Jarak ke transport publik } \\
\text { terdekat }\end{array}$ & $\begin{array}{l}5 \mathrm{~km} \text { (Stasiun Depok Lama); } \\
\text { 5,5 km (Stasiun Depok Baru) }\end{array}$ \\
\hline Jarak ke sekolah terdekat & $12,5 \mathrm{~km}$ (Universitas Indonesia) \\
\hline Jarak ke rumah sakit terdekat & 4 KM (RS Mitra Keluarga Depok) \\
\hline Jarak ke pasar terdekat & 3,5 KM (Pasar Citayam) \\
\hline Jarak ke tempat ibadah terdekat & 10 km (Masjid Kubah Mas); \\
\hline Jarak ke hotel terdekat & $\begin{array}{l}5,5 \mathrm{~km} \text { (Gereja Katolik St. Paulus) } \\
5,5 \mathrm{~km} \text { (Hotel Santika Depok) }\end{array}$ \\
\hline Jarak ke pusat pemerintahan & $5 \mathrm{~km}$ (Kantor Walikota Depok) \\
\hline Jarak ke pusat kota & $8 \mathrm{~km}$ (Depok Town Square, Margo City, dll) \\
\hline Jarak ke pusat hiburan terdekat & $\begin{array}{l}27,5 \text { KM (The Jungle Bogor); } \\
12 \text { km (Telaga Golf Sawangan) }\end{array}$ \\
\hline
\end{tabular}

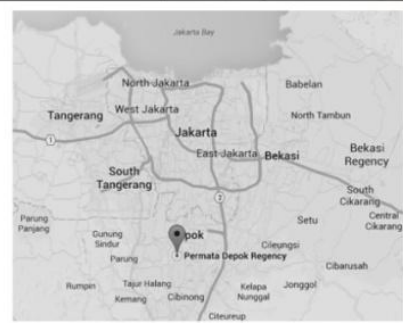


e-issn: 2229-8568

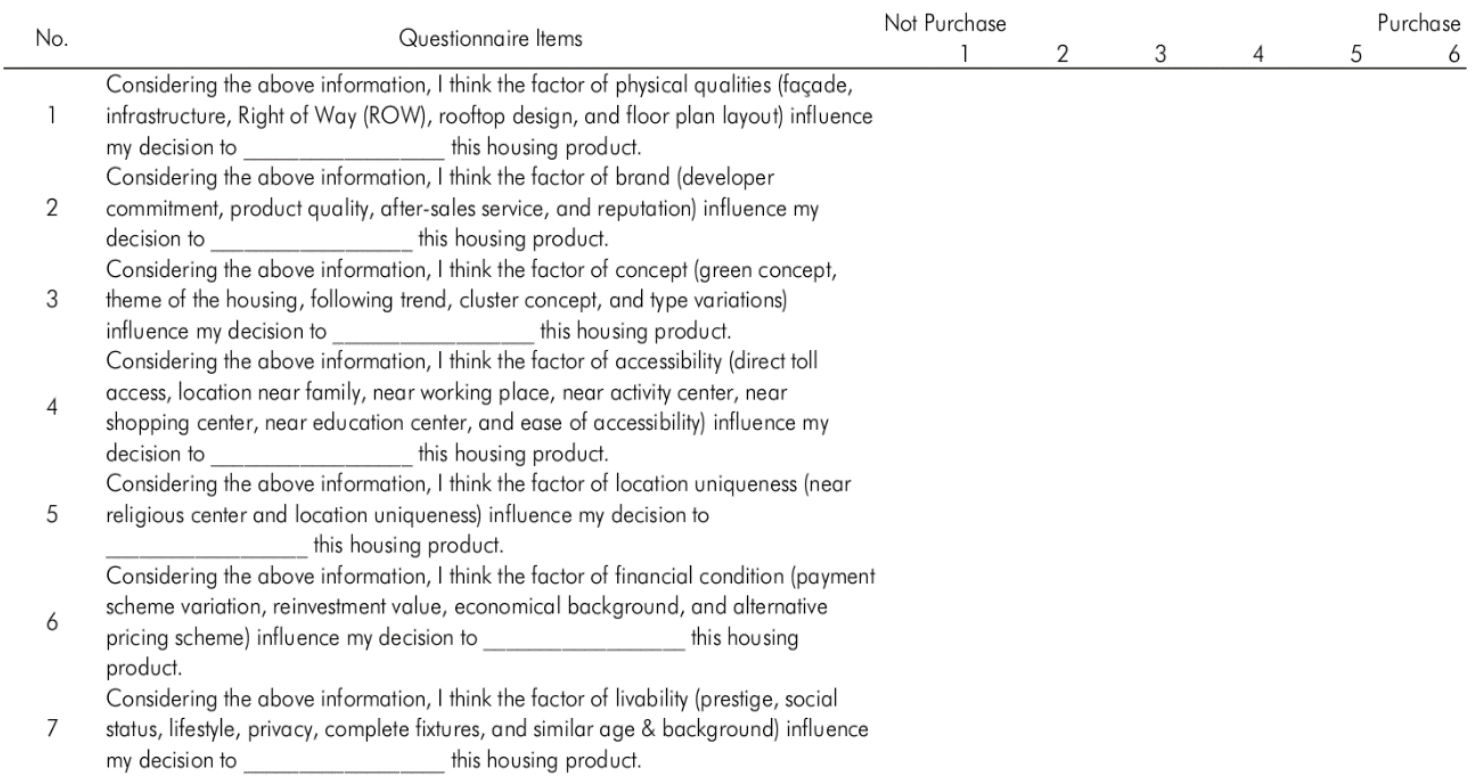

